\title{
An Investigation of Juvenile Gang Membership and Psychopathic Behavior: Evidence from Multilinear Analysis
}

\author{
G. Solomon Osho \\ Prairie View A\&M University \\ Justin Joseph \\ Prairie View A\&M University \\ Julian Scott \\ Prairie View A\&M University \\ Michael Adams \\ Texas Southern University
}

Received: April 4, 2016 Accepted: September 20, 2016 Published: September 26, 2016

doi:10.5296/10.5296/ijsw.v3i2.9312 URL: http://dx.doi.org/10.5296/ijsw.v3i2.9312

\begin{abstract}
The extant literature provides evidence that gang involvement increases and individuals propensity to perpetrate antisocial behavior. Furthermore, it has been empirically support that criminal involvement increases and individuals like-hood of experiencing victimization. Antisocial personality disorder is described as engaging in aggressive behavior that is socially unacceptable; irresponsible, impulsive behavior; merged with impaired ability to empathize with victims; indifference to social norms, and frequent substance abuse (Cox, Edens, Magyar, \& Lilienfeld, 2013; Lilienfeld \& Arkowitz, 2007). Therefore, it is logical to deduce that gang affiliation also increases the probability of victimization amongst juveniles, which has been supported by by several authors. Furthermore, considering the symptomology associated with conduct disorder and operational defiant disorder it is probable that gang
\end{abstract}


membership and victimization may have a critical role in the externalization of this psychological disorders symptoms. To examine this question we utilize data gathered by the Gang Resistance Education and Training (G.R.E.A.T) program which consists of $(\mathrm{N}=5,935)$ eight grade students from 42 different schools. These schools are located in: Arizona, California, Florida, Idaho, Illinois, Missouri, Nebraska, New Mexico, Pennsylvania, Rhode Island, and Wisconsin. The metropolitan regions the subjects reside during the data collection period are: Omaha, Las Cruces, Philadelphia, Phoenix, Torrance, Orlando, Pocatello, Will County, Kansas City, Providence, and Milwaukee. The results, limitations, and implications of the study will be discussed later.

Keywords: Antisocial behavior, Gang membership and Victimization

\section{Introduction}

The construct of psychopathy and antisocial personality disorder (APD) incorporates a manifold of variables. The DSM-V indicates that psychopathy is not an independent disorder but rather a subset of antisocial personality disorder (Cox, Edens, Magyar, Lilienfeld, Douglas, \& Poythress, 2013; Lilienfeld \& Arkowitz, 2008; Skeem, Polascheck, Patrick, \& Lilienfeld, 2011). Due to the fact that psychologists today still lack an absolute definition of what incorporates the construct of psychopathy (Cox, Edens, Magyar, Lilienfeld, Douglas, \& Poythress, 2013; Skeem \& Cooke, 2010; Skeem, Johansson, Andershed, Kerr, \& Louden, 2007; Skeem, Polascheck, Patrick, \& Lilienfeld, 2011; Smith, \& Lilienfeld, 2013).

Antisocial personality disorder is described as engaging in aggressive behavior that is socially unacceptable; irresponsible, impulsive behavior; merged with impaired ability to empathize with victims; indifference to social norms, and frequent substance abuse (Cox, Edens, Magyar, \& Lilienfeld, 2013; Lilienfeld \& Arkowitz, 2007). Features of psychopathy described within the DSM $-\mathrm{V}$ are superficial charm, grandiose sense of self-worth, pathological lying, and manipulative lack of remorse (Cox, Edens, Magyar, Lilienfeld, Douglas, \& Poythress, 2013; Lilienfeld \& Arkowitz, 2008; Skeem \& Cooke, 2010; Skeem, Johansson, Andershed, Kerr, \& Louden, 2007; Skeem, Polascheck, Patrick, \& Lilienfeld, 2011). The distinction between APD and psychopathy is that psychopathy focuses on interpersonal traits while APD focuses on criminal behavior, yet empirical studies examining the construct of psychopathy operationalize the construct through various forms of antisocial behavior (Hare \& Neumann, 2010; Raine, 2013; Skeem \& Cooke, 2010; Skeem, Polascheck, Patrick, \& Lilienfeld, 2011; Walters, 2012). Furthermore, in an attempt to predict, comprehend, and treat the form of psychological disorder the construct of developmental psychopathy was developed.

\section{Juvenile Psychopathy}

Psychopathy is characterized as lacking anxiety, guiltlessness, superficial charm, social adaptiveness, dishonesty, recklessness, and uninhibited behavior. There are several common misconceptions about psychopathy. First, is that it is synonymous with violence, psychosis and antisocial personality disorder (APD) and (2) psychopathic traits occur in conjunction with psychotic traits (rare in occurrence) (Cox, Edens, Magyar, Lilienfeld, Douglas, \& Poythress, 2013; Lilienfeld \& Arkowitz, 2008; Skeem \& Cooke, 2010; Skeem, Johansson, Andershed, Kerr, and Louden, 2007; Skeem, Polascheck, Patrick, \& Lilienfeld, 2011). 
According to (Lilienfeld \& Arkowitz, 2008; Skeem, Polascheck, Patrick, \& Lilenfeld, 2011) psychopathic individuals are born not made.

\subsection{The Development Approach for Psychopathy}

Extending the construct of psychopathy to children is an attempt to predict which children will develop into full-fledged psychopaths in adulthood. The purpose of the developmental psychopathy paradigm is to identify at risk adolescence and treatment options for them, and reduce the amount of heterogeneity for the construct within the Diagnostic Statistical Manual for Mental Disorders (DSM) (Frick, 2002; Lynam, 2001; Salekin \& Frick, 2005; Skeem, Polascheck, Patrick, \& Lilenfeld, 2011; Raine, 2013). (Frick, 2002; Frick, 2009; Salekin \& Frick, 2005; Skeem, Polascheck, Patrick, \& Lilenfeld, 2011) state unfortunately the measures for juvenile psychopathy are used to determine if youth should be tried as an adults or not within the criminal justice system. (Frick, 2002; Frick, 2005; Lynam, 2001; Skeem, Johansson, Andershed, Kerr, \& Louden, 2007; Skeem, Polascheck, Patrick, \& Lilenfeld, 2011) assert that children at risk for developing psychopathy or antisocial personality disorder are diagnosed with conduct disorder (CD or operational defiant disorder (ODD) during adolescence. Conduct disorder is described by (Frick, 2002; Frick 2005; Frick, 2009; Skeem, Polascheck, Patrick, \& Lilenfeld, 2011) as a diagnosed subgroup of youth with serious persistent antisocial behaviors.

The DSM-V allows for a distinction of two subtypes of conduct disorder, which are childhood onset and adolescent onset, the consequence of (Moffitt, 1993) hypothesis regarding juvenile psychopathy. Adolescent onset occurs between the ages of 10 through 18, while the childhood onset is prior to age 10 (Skeem et al., 2011). Due to Frick's callous unemotional hypothesis regarding the development of psychopathy a significant number of scholars have begun to create distinct categories within conduct disordered youth. (Hart, Watt, \& Vincent, 2002; Vincent \& Hart, 2002; Skeem \& Cauffman 2003) are critical of the downward extension of psychopathy to youth, on basis of unresolved developmental questions within psychopathy which limits the utility and reliability of the construct that is supported by some scholars.

(Skeem, Polascheck, Patrick, \& Lilenfeld, 2011) report that there is continuous debate within the discipline about the stability of psychopathy within children. "The basic tenets of developmental psychopathology propose that: (1) psychopathic traits can be expressed dissimilarity across stages of life-course, (2) may be the product of various etiological pathways, (3) what is perceive as psychopathy in adulthood may predispose individuals to various psychological issue in adulthood" (Skeem, Polascheck, Patrick, \& Lilenfeld, 2011). First, observable personality traits are only moderately stable at age 30 and they become highly stable once an individual reaches the age of 50. Secondly, personality traits can be fairly stable in early adolescence, but there are always considerable changes to their personality features as they mature. Furthermore, there is little longitudinal empirical evidence to support the downward extension of the construct psychopathy for juveniles. Therefore, this study attempts to examine a probable etiological pathway for the onset of conduct disorder (CD) and operational defiant disorder (ODD) through examining gang membership and its relationship with conduct disorder (CD) and operational defiant disorder (ODD). This study is attempting to answer the question "Does gang membership influence 
the externalization of CD and ODD symptoms within adolescence," (2) How much does gang membership predict the externalization of CD/ODD symptoms within youth.

\subsection{Operational Defiant Disorder \& Conduct Disorder}

Operational Defiant Disorder (ODD) and Conduct Disorder (CD) are predominant adolescent psychological disorders that are observed within the community (Loeber, Burke, Lahey, Winters, \& Zera, 2000). There is a significant amount of empirical literature supporting the distinction between these two behavioral psychological disorders. Conduct disorder is a constellation of continuous emotional and behavioral problems observed in children and adolescence, which may involve violent and non-violent antisocial behavior. The symptomology of this psychological disorder in the DSM-V are: disregarding rules without clear reason, cruel or aggressive behavior toward people or animals (for example: bullying, fighting, using dangerous weapons, forcing sexual activity, and stealing), skipping school, heavy substance, pathological lying, manipulation, running away, and vandalism. Adolescence or children with this mental disorder are impulsive, callous, and disobedient and these symptoms must persist for a period of twelve months (Loeber et al., 2000). In comparison to conduct disorder, (ODD) is considered to be a milder more manageable form of the disorder. The symptomology of (ODD) in the DSM-V is: often loose temper, argumentative with elders, frequently defies or refuses to comply with adults' requests or rules, deliberately annoys people, externalize blame for his or her mistakes or misbehavior, is often touchy or easily annoyed by other, is often angry and resentful, very vindictive (Loeber et al., 2000).

Loeber, Burke, Lahey, Winters and Zera, (2000) report that the severity of the symptoms for ODD and CD influences the stability of the symptoms throughout adolescence, into adulthood. The authors report that there are several factors regarding the early onset of conduct disorder: possessing attention deficit hyperactive disorder (ADHD) and the early onset of CD problems can be predicted by early continuous ODD symptoms. "The DSM-IV makes a distinction among different severity levels of symptoms of ODD and CD, but such distinctions are not often referred to in the psychiatric literature. In contrast, delinquency studies have demonstrated the high predictive utility of severity scaling of various forms of delinquent acts" (Loeber, Burke, Lahey, Winters, \& Zera, 2000). Additionally, the authors report that several studies have provided empirical evidence for individual involvement with violent forms of anti-social behavior in the development of disruptive behavior. Furthermore, the inclusion of callous unemotional traits as a distinguishing marker for a subtype of conduct disorder; maybe warranted because youth whom possess callous unemotional traits have continuously been identified to belong to a distinct subgroup of CD youth. Making the trait a required symptom of CD would make it feasible (Moffit, Arsenault, Jaffee, Cohen, Koenen, Odgers, Stutske, \& Viding, 2008). Furthermore, possessing the ability to distinguish this trait may be effectual for clinicians, considering and identifying probable treatment interventions for children and adolescents. Considering, the evidence that children with these traits display more proactive antisocial behavior, and it is likely that these children possess genetic predispositions for (APD) or psychological illness with similar neurological anomalies associated with it (Moffit et al., 2008).

Moffit, Arsenault, Jaffee, Cohen, Koenen, Odgers, Stutske, and Viding (2008) assert that the 
need for considering biological markers within the DSM-V may assists with comprehending neurological and genetic influences on behavior. Truly comprehending the influence of biological markers possess on individual behavior may be useful for developing near full proof treatment inventions and predictive utility within the criminal justice system. Furthermore, introducing biological markers for $\mathrm{CD}$ may alleviate bias from practitioners, and promote equitability within the discipline; and provides evidence of a homogenous aggregate of CD youth. Each of these changes to the DSM-V and future research can alleviate the issues with juvenile psychopathy and probably adult psychopathy.

\subsection{Race Relationship with Conduct Disorder}

Considering the fact that the construct of psychopathy has been proximately examined utilizing a poor Caucasian population (Skeem, Polascheck, Patrick, \& Lilenfeld, 2011), it is appropriate to conclude that juvenile adaption of psychopathy (CD/ODD) suffers from the same methodological shortcomings. The few empirical studies that have attempted to examine the moderating variable of race in relation to psychopathy and conduct disorder have produced mixed results (Skeem, Polascheck, Patrick, \& Lilenfeld, 2011). Therefore, the inclusion of race as a moderating variable in this study is important considering that majority of gangs is comprised of minority youth (Yoder, Whitbeck, \& Hoyt, 2003).

Lober, Step, Chung, Hipwell and White (2010) examine five hundred and sixty-six girls (566) derived from the oldest cohort within Pittsburg Girls Study (PGS). In order to examine the moderating variable race association to the development of early conduct problems and alcohol abuse between the ages of 11 and 15 (Lober, Step, Chung, Hipwell, White 2010). The sample was comprised of $N=318$ (56.2\%) African American adolescent girls and $\mathrm{n}=248$ (43.8\%) Caucasian adolescent females whom participated in at least one assessment. Lober, Step, Chung, Hipwell and White (2010) discovered different etiological trajectories in conduct problems between White and African American juveniles in regards to early alcohol abuse (one symptom of conduct disorder).

To provide some insight regarding what risk profiles, or factors associated with the onset of conduct disorder or operational defiant disorder symptoms debate (Wiesner, Elliot, McLaughlin, Banspatch, Tortelero, \& Schulster, 2014) examine $(N=4,705)$ community sample. This sample is comprised of African American, Mexican American, and White $5^{\text {th }}$ grade students $(49 \%)$ boys $(51 \%)$ were girls. Interestingly enough (Wiesner, Elliot, McLaughlin, Banspatch, Tortelero, \& Schulster, 2014) pattern of common and specific correlates of CD and ODD symptoms was replicated fairly consistently across the three racial/ethnic subgroups. (Gibbons, Yeh, Gerrad, Cleveland, Cutrona, Simons, \& Brody, 2007) examine how much previous racial discrimination moderated conduct disorder. The authors examined 889 African America adolescents ( $M=10.5$ at time 1). (Gibbons et al., 2007) discovered that racial discrimination experience by juveniles possess both and direct and indirect relationship with $(\mathrm{CD})$ youth.

Kaden (2010) examined pattern of conduct disordered diagnosis and therapist racial biases. They author wanted to know if minorities were more likely to receive a conduct disorder diagnosis in comparison to their white counterparts, which has been supported in previous research. (Kaden, 2010) analyzed 97 adolescents and when accounting for racial dissimilarities discovered that licensed therapists and urban therapists were found to diagnose 
Black adolescent boys with conduct disorder more frequently than they diagnosed white adolescent boys with conduct disorder. Therefore, the little empirical literature examining this phenomenon has produced mixed results regarding racial influences on conduct disorder and operation defiant disorder symptoms. Resulting in the need for inquiry regarding the topic.

\subsection{Biological Sex \& CD/ODD}

Mier, Slutske, Heath, and Martin (2011) examine how genetic or shared environmental factors influence conduct disorder by biological sex. The authors discovered, that neither the genetic nor the shared environmental factors influencing childhood conduct disorder differed for males and females, but by adulthood, these sex-specific influences on antisocial behavior were no longer apparent. Further, genetic and environmental influences accounted for proportionally the same amount of variance in antisocial behavior for males and females in childhood and adulthood. Additionally, the stability of antisocial behavior from childhood to adulthood was slightly greater for males than females (Meier et al., 2011). Fergusson (2010) examined issues relating to the measurement and discriminant validity of DSM diagnostic criteria for behavior disorders in adolescence. The disorder analyze were: conduct disorder (CD), operational defiant disorder (ODD), attention deficit-hyperactive disorder (ADHD). The results indicated that there was no evidence to suggest that the developmental consequences of CD, ODD, and ADHD differed by gender (Fergusson et. al. 2010). However, (Webster-Stratton, 1996) discovered significant gender differences in behavioral symptoms according to independent home observations. However, reports of gender differences in behavioral symptoms were influenced by the gender of the reporting agent. The only gender-specific risk factor found was father "negativity" which was correlated with boys' behavior at home but not girls' behavior (Webster-Stratton, 1996). Therefore, there are mixed findings regarding sex and conduct disorder, which are also associated with probable gender stereotypes. Considering, the fact a vast majority of gang are comprised of minority males, therefore, it suggests that race and sex are important moderator variables for the study that should be controlled for.

\subsection{Gang Membership, Criminality, and Victimization}

Gang membership increases an individual's probability of experiencing victimization, which is supported within the extant literature (Yoder, Whitbeck, \& Hoyt, 2003; Taylor, Peterson, Esbensen, \& Freng, 2007; Taylor, 2008; Taylor, Freng, Esbensen, \& Peterson, 2008; Delisi, Barnes, Beaver, \& Gibson, 2009; Webb, Ren, Zhoa, He, \& Marshall, 2011; Barnes, Boutwell, \& Fox, 2012; Bendixen, Endersen, \& Olwens, 2006). This may be the result of the delinquent mediating relationship associated with gang membership (Bendixen, Endersen, \& Olwens, 2006). There are a myriad of plausible explanations for this phenomena, increased involvement in antisocial behavior (drug trafficking), gang wars, retaliation. Furthermore, gang member are more likely to experience victimization from members within their gang in comparison to rival gang members (Taylor, Peterson, Esbensen, \& Freng, 2007). Even though there is substantial evidence (Yoder, Whitbeck, \& Hoyt, 2003; Taylor, Peterson, Esbensen, \& Freng, 2007; Taylor, 2008; Taylor, Freng, Esbensen, \& Peterson, 2008; Delisi, Barnes, Beaver, \& Gibson, 2009; Webb, Ren, Zhoa, He, \& Marshall, 2011; Barnes, Boutwell, \& Fox, 2012) also report that gang members are likely to perpetrate more criminality in comparison to their non-delinquent peers. The literature has provided evidence: (1) that males are more likely to 


\section{N Macrothink}

join gangs, (2) gang members are usually younger than non-members, (3) gang members are derived from low socioeconomic regions, and (4) minorities are more likely to involve themselves with gangs (https://www.nationalgangcenter.gov/survey-analysis/demographics; Yoder, Whitbeck, \& Hoyt, 2003). Gang members are more likely to possess diminished educational aspirations, grades, insecure attachments with the educational social structure, and possess significantly more deviant peers (Yoder, Whitbeck, \& Hoyt, 2003).

There are five categories of risk protective factors identified within the extant literature which are categorized into individual, family, peer, school, and community (Taylor, Peterson, Esbensen, \& Freng, 2007). Individual risk and protective factor that are associated with violent victimization are: self-control, demographics, guilt and neutralizations. Family factors include parental monitoring, attachment styles with guardians (Taylor, Peterson, Esbensen, \& Freng, 2007). Peer domain encompass commitment to sociably acceptable behavior, delinquent peers. The school factors include school climate and the individual's commitment to school. Lastly the situational domain incorporates lifestyles and routine activities that the adolescence involves themselves with. For instance, attending parties, substance/alcohol abuse, unstructured leisure time, and region they may frequently visit (Taylor, Peterson, Esbensen, \& Freng, 2007).

Yoder, Whitbeck, Hoyt (2003) examined the empirical models proposed by Thornberry and his colleagues in 1993 (selection model), and the expanded models proposed by Dukes and colleagues in 1997 (facilitation model). The selection model postulates that gang target individuals whom they think has a propensity for delinquency. While the facilitation model presumes that gang recruiters perceive individuals as non-delinquent and through the socialization process these individuals experience within the gang they become full-fledged gang members (Bendixen, Endersen, \& Olwens, 2006). Therefore, this model postulates the delinquency will peak during gang member and will desist post gang membership (Bendixen, Endersen, \& Olwens, 2006). (Yoder, Whitbeck, Hoyt, 2003) hypothesized: (1) "the selection model operates for socio-demographic features, family background, school/ street experience and exposure, and emotional issues; and (2) the facilitation model will effective for delinquency." The authors analyzed 602 homeless and runaway youth from the Midwest Homeless and Runaway Adolescent Project (MHRAP) which provides service Iowa, Kansas, Missouri, Nebraska. Of the 602 participants $60 \%$ were female, the remaining male around the age of 16. Majority of the participants were Caucasian (60.1\%), African American (24. 1\%), Hispanic (3.3\%), Native American (2.5\%), and biracial, multi-racial (10\%) (Yoder et al., 2003). (Yoder, Whitbeck, \& Hoyt, 2003) found some evidence for the selection model in regards to family legal issues, school suspension, age first on their own, delinquent peers, and suicide attempts, the remaining variables displayed no statistical significance. The authors report that they discovered evidence for the facilitation model in regards to substance abuse, and that gang members were involved in more delinquency in-comparison to their counterparts. Finally, the authors concluded that majority of the youth experience victimization perpetrated by family members, and peers.

Bendixen, Endersen, and Olwens, (2006) examine the selection model, facilitation model, alongside the mixed enhancement model. The mixed enhancement model postulates that gang recruit seek out delinquent juveniles throughout their neighborhood. Once these individuals 
are within the gang their subculture proliferates the amount of antisocial behavior perpetrated by the individual. Therefore, it is a mixture of both the selection and facilitation model (Bendixen, Endersen, \& Olwens, 2006). The authors examined students $(N=1,203)$ grades fifth through eighth students derived from Bergen in Norway whom were apart of Dan Olweus Bullying Prevention Program. The authors inquired about general antisocial behavior, violent behavior, and gang membership. (Bendixen, Endersen, \& Olwens, 2006) discovered support for both selection and facilitation process to some varying degree. The between subject analysis discovered that gang members perpetrated more general criminality (before, during, and after) in comparison to the control group. The selection effect was stronger for boys and possess a moderate effect throughout the sample. Furthermore, the authors found that majority of criminality was perpetrated during gang membership in comparison to gang non-membership. This evidence provides support for the enhance model proposed by Thornberry.

Taylor, Peterson, Esbensen, Freng, (2007) examined three specific questions: (1) how gang member and non-gang members differ in terms of violent victimization? (2) assuming differences exist, what factors account for differences in the extent of violent victimization between gang members and non-gang members; and (3) does gang membership remain a salient correlate of violent victimization, once other relevant factors are controlled?" Through examining the features that incorporate the risks and protective factors identified in previous research. The authors examined 5,935 eight grade youth from a multi-site study which included 11 sites from various states throughout the nation representing 335 classrooms, and 42 schools. The authors discovered that juveniles involved in gang activity possessed protective factors in comparison to non-gang affiliated youth. That gang membership provided a buffer for general violent victimization, amalgamated with an increased risks of serious violent victimization. One mitigating factor involved in these findings are that gang members are more likely to engage in unsupervised activities and place themselves in risky situations.

Webb, Ren, Zhoa, He, and Marshall (2011) compared China gang behavior to gang behavior observed within the West. The authors utilized a multi- cluster sampling technique to gather participants for the study. (Webb, Ren, Zhoa, He, \& Marshall, 2011) used the second International Self-Report Delinquency (ISRD-2) and pretested the instrument on 16 Chinese foreign exchange students to accommodate for cultural dissimilarities. The study consisted of 862 Chinese participants within the sample and while the United States sample possessed 2,041. American juveniles were more likely to report perpetrating delinquency in comparison to their Asian counterparts. Conversely, when ask the question "Do you consider the group of friends you hang with a gang" the Chinese youth were five times more likely to answer yes in regards to the U.S counterparts (Webb, Ren, Zhoa, He, \& Marshall, 2011). Furthermore, there were less actual gangs within China than within the U.S and that the gangs within China were not involved in illegal drug trafficking and severe violent crimes. Finally, it provides distinct evidence of the cultural dissimilarities in regards to the gang subculture.

\subsection{Victimization and $C D / O D D$}

(Skeem, Poythress, Edens, Lilienfeld, \& Cale, 2003; Skeem, Johansson, Andershed, Kerr, \& Louden, 2007) report that secondary psychopaths may possess traits on par with borderline 
personality disorders. (Skeem, Poythress, Edens, Lilienfeld, \& Cale, 2003; Skeem, Johansson, Andershed, Kerr, \& Louden, 2007; Kimonis et al., 2012) found that secondary variants (high anxious types) experience negative emotionality and childhood abuse. Conversely, primary variants (low anxious types) are less likely to experience negative emotionality. Barker and Salekin (2012) examined 5,903 child parent pairs from the Avon Longitudinal Study of Parents and Children and discovered that peer victimization predicted the development of callous unemotional traits and difficulties internalizing emotional problems amongst juveniles. Fanti and Kimonis (2012) examined 1,416 Greek-Cyproit adolescence ages 12 to 14 and discovered that adolescents whom scored high on Narcissism, conduct problems, and impulsivity score high on callous unemotional traits perpetrated more bullying behaviors. Bullying was more stable amongst youth scoring high on narcissism and victimization were high for juveniles whom scored high on impulsivity (Fanti \& Kimonis, 2012).

In conclusion there are a multitude of factors influencing the externalization of $\mathrm{CD} / \mathrm{ODD}$ amongst juveniles, which is measure through delinquency by scholars. The extant literature provides evidence that victimization, disorganized family histories, sex, genetic predispositions, social learning variables, and comorbidity of psychological disorders influence the externalization of CD/ODD symptoms and the degrees at which they are externalized. Considering this it is plausible to presume that gang membership is a clear predictor for juvenile delinquency, because gang subculture encompasses a lot of these predictor variables and is comprised of majority minority males, yet interestingly enough there is no empirical evidence examining gang membership and CD/ODD symptoms.

Therefore, the purpose of this research is to increase the comprehension of the psychological phenomena $\mathrm{CD} / \mathrm{ODD}$ through examining how much of an influence does gang membership exacerbate these symptoms. Furthermore, provide unique way of understanding CD/ODD youth throughout the criminal justice system and why some persists into life persistent criminals (a social image of psychopathy). Finally, with this comprehending more effective intervention techniques may be utilized to combat this psychological phenomena and decrease the amount of recidivists nationwide.

\section{Method}

There is evidence throughout the literature regarding victimization and symptoms of $\mathrm{CD} / \mathrm{ODD}$, and criminality. There is little research regarding how gang membership may influence the externalization of CD/ODD symptoms within juveniles. Furthermore, there is little evidence on the extent into which victimization influences the externalization of $\mathrm{CD} / \mathrm{ODD}$ symptoms. This study attempts to answer this question within this area of research providing professional's with a more comprehensive understanding of juveniles who may be diagnosed with this disorder.

\subsection{Research Design}

The population for this study is a group of middle school juveniles derived from the Gang Resistance Education and Training (G.R.E.A.T). This data set consists of $(N=5,935)$ eight grade students from 42 different schools. These schools are located in: Arizona, California, Florida, Idaho, Illinois, Missouri, Nebraska, New Mexico, Pennsylvania, Rhode Island, and Wisconsin. The metropolitan regions the subjects reside during the data collection period are: 
Omaha, Las Cruces, Philadelphia, Phoenix, Torrance, Orlando, Pocatello, Will County, Kansas City, Providence, and Milwaukee. This dataset, is comprised of: Whites (40\%), African Americans (26\%), Hispanics (19\%), American Indians (2\%), Asians Pacific (6\%), Others $(2 \%)$ of the surveyed population, and mixed race $(4 \%)$. Furthermore, the original dataset displays that for family structure, (61\%) live with both parents, (31\%) from single parent homes, $(2 \%)$ live with grandparents, and (1\%) with their parent and other relative, and $(1 \%)$ reside with other relatives. Within the original dataset $(48 \%)$ are males while $(51 \%)$ are females. Finally, of the original dataset 5,226 (88.1\%) participants identified as non-gang member, $522(8.8 \%)$ were currently in a gang, and 187 (3.2\%) did not report anything at all.

From the (G.R.E.A.T) data set the study utilizes two scales to examine the callous/unemotional features of conduct disorder (CD) and (ODD) and delinquency/antisocial behavior within the psychological disorder. To ensure that the items are related to some extent, the study performs a factor analysis. Table (1) displays a reported KMO of (.927) above the recommended value of .6, suggesting that the sample size is sufficient for this analysis. Furthermore, (Table 1) Barlett's displays a significant relationship between the selected variables $\left(X^{2}(120)=36466.472, p<.001\right)$. In (Figure 2) the eigenvalues report that there are 2 two underlying constructs present within the data (Facet 1,2) that account for the majority of the variance between the selected items.

Table 1. KMO and Bartlett's test and total variance explained

\begin{tabular}{lll}
\hline Kaiser-Meyer-Olkin Measure of Sampling Adequacy. & .927 \\
\hline Bartlett's Test of Sphericity & Approx. Chi-Square & 36466.472 \\
& df & 120 \\
& Sig. & .000 \\
\hline
\end{tabular}

Total Variance Explained

\begin{tabular}{|c|c|c|c|c|c|c|c|c|c|}
\hline \multirow{2}{*}{ Component } & \multicolumn{3}{|c|}{ Initial Eigenvalues } & \multicolumn{3}{|c|}{$\begin{array}{c}\text { Extraction Sums of Squared } \\
\text { Loadings }\end{array}$} & \multicolumn{3}{|c|}{$\begin{array}{c}\text { Rotation Sums of Squared } \\
\text { Loadings }\end{array}$} \\
\hline & Total & $\begin{array}{c}\% \text { of } \\
\text { Variance }\end{array}$ & Cum \% & Total & $\begin{array}{c}\% \text { of } \\
\text { Variance }\end{array}$ & Cum \% & Total & $\begin{array}{c}\% \text { of } \\
\text { Variance }\end{array}$ & Cum \% \\
\hline 1 & 6.403 & 40.018 & 40.018 & 6.40 & 40.018 & 40.018 & 6.122 & 38.260 & 38.260 \\
\hline 2 & 4.408 & 27.552 & 67.570 & 4.40 & 27.552 & 67.570 & 4.690 & 29.310 & 67.570 \\
\hline 3 & .790 & 4.935 & 72.504 & & & & & & \\
\hline 4 & .723 & 4.517 & 77.022 & & & & & & \\
\hline 5 & .565 & 3.531 & 80.553 & & & & & & \\
\hline 6 & .510 & 3.184 & 83.738 & & & & & & \\
\hline 7 & .443 & 2.770 & 86.508 & & & & & & \\
\hline 8 & .435 & 2.719 & 89.227 & & & & & & \\
\hline
\end{tabular}




\begin{tabular}{cccc}
\hline 9 & .342 & 2.139 & 91.366 \\
10 & .341 & 2.133 & 93.498 \\
11 & .299 & 1.870 & 95.369 \\
12 & .231 & 1.444 & 96.813 \\
13 & .192 & 1.203 & 98.016 \\
14 & .143 & .892 & 98.908 \\
15 & .099 & .616 & 99.524 \\
16 & .076 & .476 & 100.00 \\
\hline
\end{tabular}

Extraction Method: Principal Component Analysis.

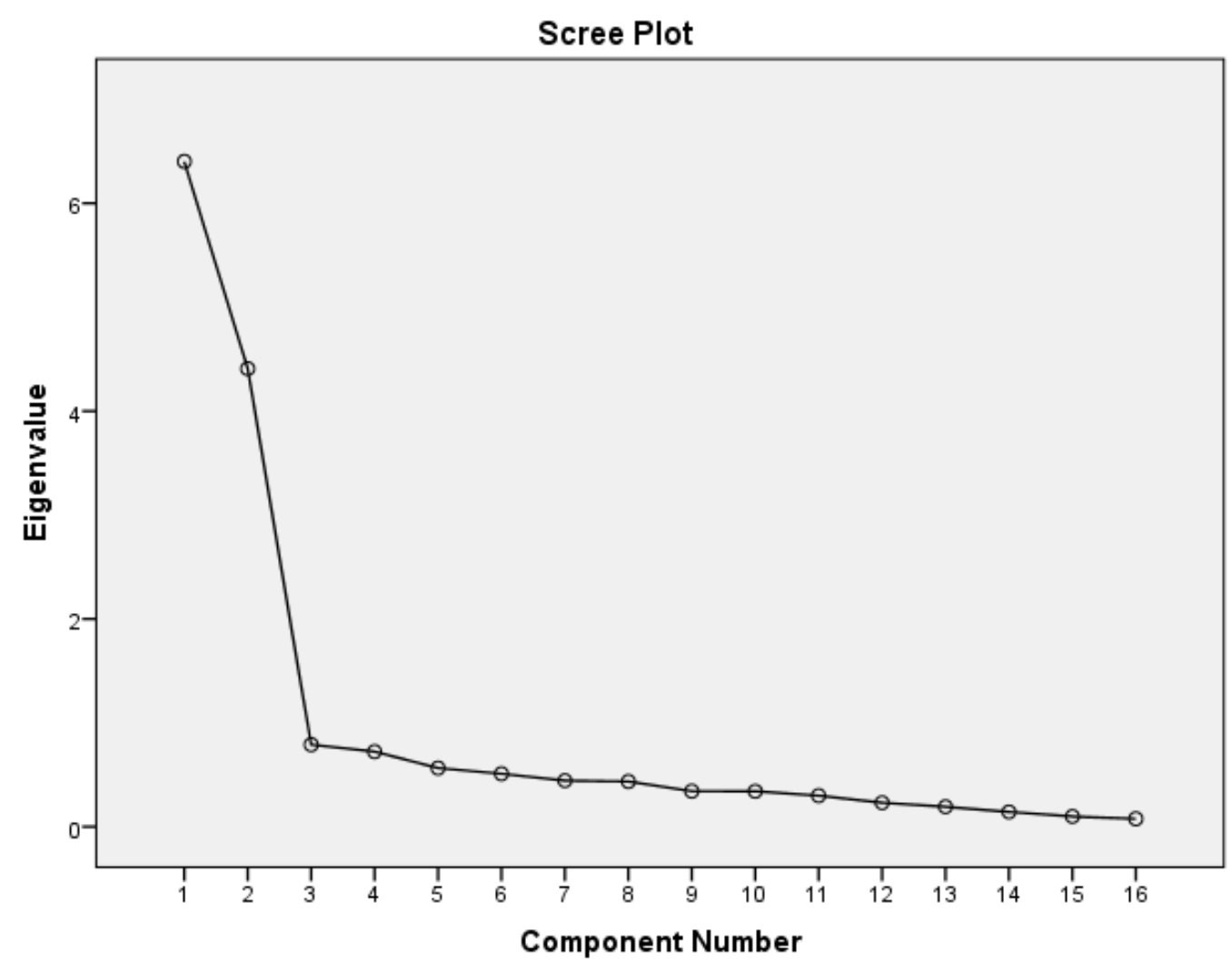

Figure 1. Screen plot

The items that incorporate Facet 1 (callous/unemotional) of the proxy CD/ODD scale: (1) Feel guilty for entering building to steal, (2) Guilty attacking someone with weapon, (3) Guilty armed robbery, (4) Guilty hitting someone, (5) Guilty using marijuana, (6) Guilty using tobacco, (8) Feel guilty skipping school see (Table 3). Facet 1 includes 7 items which produces a Cronbach's alpha of (.865).

Facet 2 represents the delinquency/antisocial behavior component of CD/ODD and Facet 1 represents the callous/unemotional features of CD/ODD. The items that make up Facet 2 
(delinquency/antisocial) of the proxy CD/ODD scale are: (1) Times used marijuana, (2) Times used tobacco, (3) Times skipped class, (4) Times go into building to steal, (5) Times hit someone, (6) Times armed robbery, (7) Times attack someone with weapon, (8) and Time shot someone when told to see (Table 2). Facet 2 produces a Cronbach's alpha (.990) suggesting that Facet 1 is very reliable see (Table 6).

The independent variable for this study are: gang membership. Moderating variables are: race, age, and sex of the respondent, and the mediating variable is the guardian the respondent live with. Gang membership is simply measured by juveniles whom admit to being a part of a gang.

Table 2. Rotated component matrix $^{\mathrm{a}}$

\begin{tabular}{|c|c|c|}
\hline & \multicolumn{2}{|c|}{ Component } \\
\hline & 1 & 2 \\
\hline FEEL GUILTY ENTERING BUILDING TO STEAL & -.065 & .750 \\
\hline GUILTY ATTACKING SOMEONE WITH WEAPON & -.069 & .754 \\
\hline TIMES SHOT SOMEONE WHEN TOLD TO & .932 & -.013 \\
\hline TIMES ATTACK WITH WEAPON & .934 & -.018 \\
\hline GUILTY ARMED ROBBERY & -.031 & .769 \\
\hline TIMES ARMED ROBBERY & .953 & -.018 \\
\hline TIMES HIT SOMEONE & .723 & -.096 \\
\hline TIMES GO INTO BUILDING TO STEAL & .916 & -.064 \\
\hline TIMES SKIPPED CLASS & .851 & -.013 \\
\hline TIMES USED TOBACCO & .801 & -.160 \\
\hline TIMES USED MARIJUANA & .849 & -.080 \\
\hline FEEL GUILTY SKIPPING SCHOOL & -.058 & .636 \\
\hline GUILTY HITING SOMEONE & -.039 & .687 \\
\hline GUILTY SELLING MARIJUANA & -.076 & .850 \\
\hline GUILTY USING TOBACCO & -.035 & .789 \\
\hline GUILTY USING MARIJUANA & -.038 & .837 \\
\hline
\end{tabular}

Extraction Method: Principal Component Analysis.

Rotation Method: Varimax with Kaiser Normalization. ${ }^{\text {a }}$

a. Rotation converged in 3 iterations.

The dependent variables will be the composite $\mathrm{CD} / \mathrm{ODD}$ scale. Therefore, we will utilize scales which examine serious delinquency, amongst adolescence considering (Loeber, Burke, Lahey, Winters, \& Zera, 2000; Frick, 2002; Frick, 2005; Frick, 2009; Skeem, Polascheck, Patrick, \& Lilenfeld, 2011) description of symptomology CD youth. To examine ODD 
symptomology, I utilize scales which examine milder forms of delinquency considering (Loeber, Burke, Lahey, Winters, \& Zera, 2000; Moffit, 2008) description of ODD. I will perform both a multiple linear regression of correlation coefficients to analyze the data.

\section{Results}

A multiple linear regression of correlation coefficients was performed to see if gang membership predicted Facet $1 \mathrm{CD} / \mathrm{ODD}$ symptoms within juveniles. The results in (Table 6 $\& 7$ ) examination the relationship between the five variables: race, sex, age, living with, and gang membership and all 5 explained $11.8 \%$ of the variance $\left(R^{2}=.118, F(5,2550)=69.312, p\right.$ $<.01$ ), indicating that it possessed significant positive regression weights. Additionally, we find that following: (a) the unstandardized slope for sex (1.046) and standardized slope are statistically (.145) different from $0(t=7.726, d f=5, p<.001)$. Therefore, females were more likely to score high within the callous/unemotional domain of conduct within this sample. Furthermore gang membership produced: (a) the unstandardized slope for gang membership $(-3.830)$, and (b) standardized slope (-2.96) are statistically different from $0(t=-15.759, d f=$ $5, p<.001)$. Therefore, individuals whom were not involved in a gang are more likely to possess the callous/unemotional disposition association with $\mathrm{CD} / \mathrm{ODD}$.

A multiple linear regression of correlation coefficients was performed to see if gang membership predicted Facet 2 CD/ODD symptoms within juveniles. The results in (Table 6 $\& 7$ ) examination the relationship between the five variables: race, sex, age, living with, and gang membership and all 5 explained $5.4 \%$ of the variance $\left(R^{2}=.054, F(5,1156)=14.242, p\right.$ $<.01$ ), indicating that it possessed significant positive regression weights. Additionally, we find that following: (a) the unstandardized slope for sex (-4.954) and standardized slope are statistically (-(-.064) different from $0(t=-2.226, d f=5, p<.05)$. Therefore, males were more likely to score high within the antisocial/delinquency domain of CD/ODD within this sample. Secondly, race produced: (a) the unstandardized slope for race (1.382), and (b) standardized slope (.062) are statistically different from $0(t=2.147, d f=5, p<.05)$. Therefore, minorities were more likely to be involved in delinquency/antisocial behavior Facet 2 of CD/ODD. Finally, gang membership produced: (a) the unstandardized slope for gang membership $(-21.920)$, and (b) standardized slope (.212) is statistically different from $0(t=7.330, d f=5$, $p<.001)$. Therefore, individuals who are involved in a gang are more likely to perpetrate delinquent/antisocial behavior that can be associated with CD/ODD.

Table 3. Callous unemotional scale

Reliability Statistics

\begin{tabular}{ll}
\hline Cronbach's Alpha & N of Items \\
.865 & 7 \\
\hline
\end{tabular}

Table 4. Scale: antisocial/delinquency scale

Reliability Statistics

Cronbach's Alpha

$\mathrm{N}$ of Items 
Table 5. Model summary

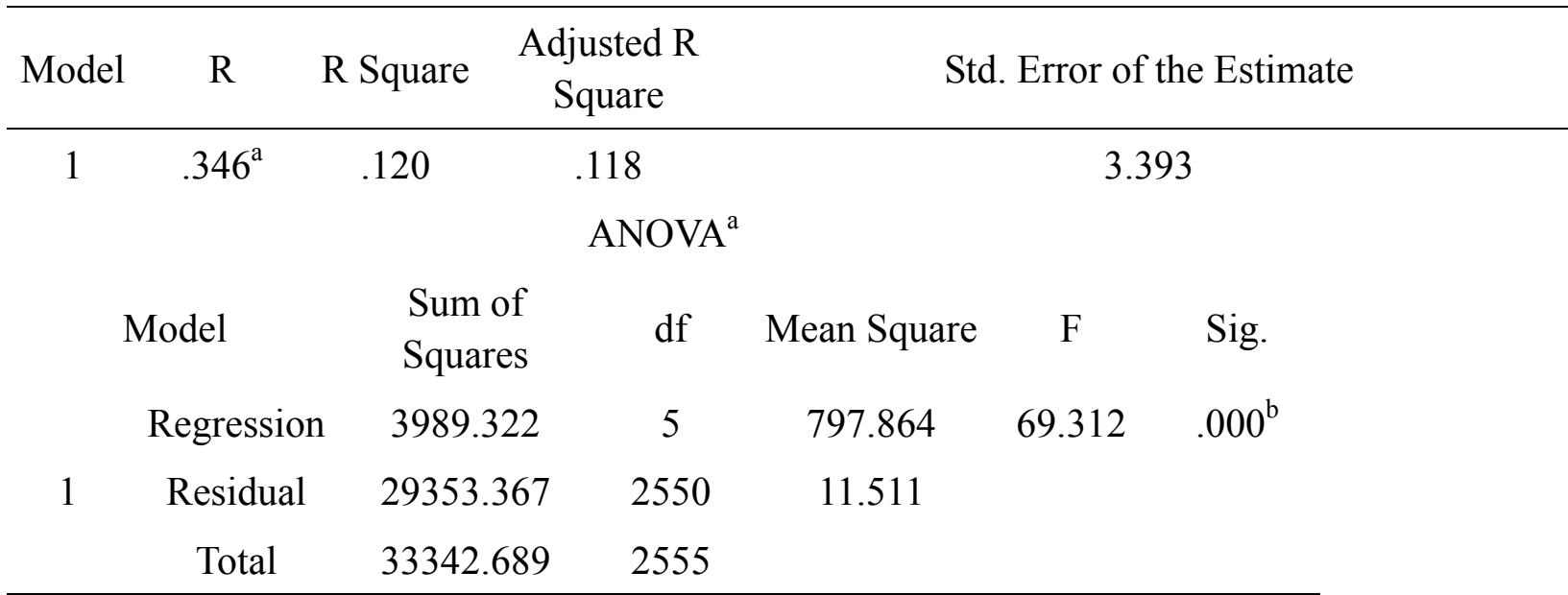

a. Dependent Variable: Callous/Unemotional Scale

b. Predictors: (Constant), EVER BEEN GANG MEMBER, AGE, LIVE WITH, RACE, SEX

Coefficients $^{\mathrm{a}}$

\begin{tabular}{|c|c|c|c|c|c|c|}
\hline & \multirow[t]{2}{*}{ Model } & \multicolumn{2}{|c|}{$\begin{array}{c}\text { Unstandardized } \\
\text { Coefficients }\end{array}$} & \multirow{2}{*}{$\frac{\begin{array}{c}\text { Standardized } \\
\text { Coefficients }\end{array}}{\text { Beta }}$} & \multirow[t]{2}{*}{$\mathrm{t}$} & \multirow{2}{*}{ Sig. } \\
\hline & & B & Std. Error & & & \\
\hline \multirow{6}{*}{1} & (Constant) & 20.457 & .393 & & 52.085 & .000 \\
\hline & SEX & 1.046 & .135 & .145 & 7.726 & .000 \\
\hline & RACE & -.051 & .038 & -.025 & -1.337 & .181 \\
\hline & AGE & .001 & .001 & .014 & .734 & .463 \\
\hline & LIVE WITH & .074 & .059 & .023 & 1.237 & .216 \\
\hline & $\begin{array}{c}\text { EVER BEEN GANG } \\
\text { MEMBER }\end{array}$ & -3.830 & .243 & -.296 & -15.759 & .000 \\
\hline
\end{tabular}

a. Dependent Variable: Callous/Unemotional Scale 
Table 6. Model summary

\begin{tabular}{|c|c|c|c|c|c|c|c|}
\hline Model & $\mathrm{R}$ & R Square & $\begin{array}{r}\text { Adj } \\
\text { Sc }\end{array}$ & $\begin{array}{l}\text { ted } \mathrm{R} \\
\text { are }\end{array}$ & \multicolumn{3}{|c|}{ Std. Error of the Estimate } \\
\hline \multirow[t]{4}{*}{1} & $.241^{\mathrm{a}}$ & .058 & & & \multicolumn{3}{|c|}{37.173} \\
\hline & \multicolumn{7}{|c|}{ ANOVA $^{\mathrm{a}}$} \\
\hline & Model & $\begin{array}{l}\text { Sum } \\
\text { Squa }\end{array}$ & & df & Mean Square & $\mathrm{F}$ & Sig. \\
\hline & Regression & 98400 & 215 & 5 & 19680.043 & 14.242 & $.000^{\mathrm{b}}$ \\
\hline \multirow[t]{2}{*}{1} & Residual & 159738 & .247 & 1156 & 1381.819 & & \\
\hline & Total & 169578 & .462 & 1161 & & & \\
\hline
\end{tabular}

a. Dependent Variable: Delinquency/Antisocial behavior Scale

b. Predictors: (Constant), EVER BEEN GANG MEMBER, LIVE WITH, AGE, SEX, RACE

Coefficients $^{\mathrm{a}}$

\begin{tabular}{|c|c|c|c|c|c|c|}
\hline & \multirow[b]{2}{*}{ Model } & \multicolumn{2}{|c|}{$\begin{array}{l}\text { Unstandardized } \\
\text { Coefficients }\end{array}$} & \multirow{2}{*}{$\begin{array}{c}\begin{array}{c}\text { Standardized } \\
\text { Coefficients }\end{array} \\
\text { Beta }\end{array}$} & \multirow[b]{2}{*}{$\mathrm{t}$} & \multirow[b]{2}{*}{ Sig. } \\
\hline & & $\mathrm{B}$ & Std. Error & & & \\
\hline \multirow[t]{6}{*}{1} & (Constant) & -6.268 & 5.570 & & -1.125 & .261 \\
\hline & SEX & -4.954 & 2.222 & -.064 & -2.229 & .026 \\
\hline & RACE & 1.382 & .644 & .062 & 2.147 & .032 \\
\hline & $\mathrm{AGE}$ & -.010 & .022 & -.013 & -.449 & .653 \\
\hline & LIVE WITH & -.347 & .895 & -.011 & -.388 & .698 \\
\hline & $\begin{array}{c}\text { EVER BEEN GANG } \\
\text { MEMBER }\end{array}$ & 21.920 & 2.990 & .212 & 7.330 & .000 \\
\hline
\end{tabular}

a. Dependent Variable: Delinquency/Antisocial behavior Scale

\section{Conclusion}

The results from the present study support our hypothesis that that gang membership is associated with the externalization (Facet 2) of CD/ODD symptoms within juveniles. Interestingly enough we discovered that race and sex were significantly also related to the externalization (Facet 2) of CD/ODD symptoms. As supported with the extant literature males are more likely to be involved with various forms of delinquency/antisocial behavior than their female counterparts (Steffensmeier \& Allan, 1996; Uggen \& Kruttschnitt, 1998; Moffit, 2001; Broidy, Cauffman, Espelage, Mazerolle, \& Piquero, 2003; Synder \& Sickmund, 2006). Interestingly, the results display that females were more likely to possess internalized (Facet 1) symptoms associated with $\mathrm{CD} / \mathrm{ODD}$, therefore it may be a sex difference that also 
must be considered within the (CD/ODD) variant perspective proposed by (Fowles \& Dino, 2009). It is probable that females are more susceptible to the primary variant associated with $\mathrm{CD} / \mathrm{ODD}$, whiles males are more likely to express the secondary variant of $\mathrm{CD} / \mathrm{ODD}$, but this is outside the realm of this particular study.

Another interesting finding supported within this study is that minorities are more likely to be involved in delinquency/antisocial (Facet 2) of CD/ODD behavior than whites which are supported by (Synder \& Sickmund, 2006), these results should be interpreted with caution, because gang membership is a mediating variable within this relationship; considering that minorities make-up majority of the composition in reported street gangs (https://www.nationalgangcenter.gov/survey-analysis/demographics; Yoder, Whitbeck, \& Hoyt, 2003). Furthermore, (UCR, 2012) data reports that juvenile whites (65.2\%) were arrested for crimes, (32.2\%) were African American juveniles, the remaining (2.5\%) were juveniles from other minority groups. The (UCR, 2012) data displays that African American juveniles accounted for $(51.5 \%)$ of all juveniles arrested for violent crimes. While Caucasian adolescents accounted for $(61.6 \%)$ of all juveniles arrested for property crimes. Therefore, it may be safe to presume that minorities may be significantly more vulnerable to receiving the diagnosis of CD/ODD, when considering the symptomology of CD/ODD with the DSM-V. Furthermore, these mixed results provide evidence that more research regarding race and CD/ODD must be performed, while also be culturally and socio-economic class sensitive.

Finally the most interesting statistically significant finding is that non gang members were highly associated with Facet 1 (callous/unemotional) traits of CD/ODD. There are several possible explanations for this phenomena, it is highly probable that a vast majority were involved in minor offenses, therefore did not feel the need to feel remorse about something like "skipping class". Majority of the participants within the data are not gang members therefore, it is high probable that they are not involved in serious delinquency, therefore utilizing (Matza \& Sykes, 1957) neutralization principles rationalizing their criminal behavior. Additionally, these individuals are not involved in the hyper masculine subculture associated with gangs (Woods, Alleyne, Mozova, \& James, 2014; Brotherton, 2008; Knox, 2004) therefore they are more susceptible to experiencing and reporting empathy for delinquency. Lastly, considering that majority of males are involved in gang activity (https://www.nationalgangcenter.gov/survey-analysis/demographics; Yoder, Whitbeck, Hoyt, 2003), it likely that proportion of females within the sample are shifting our results.

Reliance upon a proxy sample is not idea and may not accurately represent the construct of $\mathrm{CD} / \mathrm{ODD}$ considering that the data set was not intended for that purpose. The G.R.E.A.T. data set was develop with the intuition of examine juvenile gang behavior and discerning effective intervention strategies for at risk youth. Secondly reliance upon self-reports instruments does not warrant guarantee accurate results within the data. Thirdly, the lack of psychometric instrument utilized by professional within the field to examine and determine individuals with $\mathrm{CD} / \mathrm{ODD}$. Finally, utilization of primary data is associated with a number of limitations, but is useful for timely publications. Provides more insight into the construct of CD/ODD, and can be utilized to develop effective interventions and screening techniques by individuals. Furthermore, may assists scholars in the development of a unitary construct for examining, comprehending, and interpreting CD/ODD. Furthermore, may remove some the bias 
professionals may possess within the field and examine it from more of an egalitarian perspective.

\section{References}

Barker, E. D., \& Salekin, R. T. (2012). Irritable oppositional defiance and callous unemotional traits: is the association partially explained by peer victimization? Journal of $\begin{array}{llll}\text { Child Psychology and Psychiatry, 53(11), 1167-1175. } & \text { and }\end{array}$ http://dx.doi.org/10.1111/j.1469-7610.2012.02579.x

Barnes, J. C., Boutwell, B. B., \& Fox, K. A. (2012). A biosocial examination of the gangvictimization relationship. Youth Violence and Juvenile Justice, 10, 227-244. http://dx.doi.org/10.1177/1541204011429948

Bendixen, M., Endresen, I. M., \& Olweus, D. (2006). Joining and leaving gangs selection and facilitation effects on self-reported antisocial behaviour in early adolescence. European Journal of Criminology, 3(1), 85-114. http://dx.doi.org/10.1177/1477370806059082

Broidy, L., Cauffman, E., Espelage, D. L., Mazerolle, P., \& Piquero, A. (2003). Sex differences in empathy and its relation to juvenile offending. Violence and Victims, 18(5), 503-516. http://dx.doi.org/10.1891/vivi.2003.18.5.503

Brotherton, D. C. (2008). 7. Youth Subcultures, Resistance, and the Street Organization in Late Modern New York. Globalizing the Streets: Cross-cultural Perspectives on Youth, Social Control, and Empowerment, 114.

Cox, J., Edens, J. F., Magyar, M. S., Lilienfeld, S. O., Douglas, K. S., \& Poythress Jr, N. G. (2013). Using the Psychopathic Personality Inventory to identify subtypes of antisocial personality disorder. Journal of Criminal Justice, 41(2), 125-134. http://dx.doi.org/10.1016/j.jcrimjus.2012.12.001

DeLisi, M., Barnes, J. C., Beaver, K. M., \& Gibson, C. L. (2009). Delinquent gangs and adolescent victimization revisited a propensity score matching approach. Criminal Justice and Behavior, 36(8), 808-823. http://dx.doi.org/10.1177/0093854809337703

Fanti, K. A., \& Kimonis, E. R. (2012). Bullying and victimization: The role of conduct problems and psychopathic traits. Journal of Research on Adolescence, 22(4), 617-631. http://dx.doi.org/10.1111/j.1532-7795.2012.00809.x

Fowles, D. C., \& Dindo, L. (2009). Temperament and Psychopathy A Dual-Pathway Model. Current Directions in Psychological Science, 18(3), 179-183. http://dx.doi.org/10.1111/j.1467-8721.2009.01632.x

Frick, P. J. (2002). Juvenile Psychopathy From a Developmental Perspective. Law and Human Behavior, 26(2), 247-253. http://dx.doi.org/10.1023/A:1014600311758

Frick, P. J., Stickle, T. R., Dandreaux, D. M., Farrell, J. M., \& Kimonis, E. R. (2005). Callous-unemotional traits in predicting the severity and stability of conduct problems and delinquency. Journal of abnormal child psychology, 33(4), 471-487. http://dx.doi.org/10.1007/s10648-005-5728-9

Frick, P. J. (2009). Extending the construct of psychopathy to youth: implications for understanding, diagnosing, and treating antisocial children and adolescents. Canadian Journal of Psychiatry/Revue canadienne de psychiatrie, 31(12), 803. 
Gibbons, F. X., Yeh, H. C., Gerrard, M., Cleveland, M. J., Cutrona, C., Simons, R. L., \& Brody, G. H. (2007). Early experience with racial discrimination and conduct disorder as predictors of subsequent drug use: A critical period hypothesis. Drug and Alcohol Dependence, 88, S27-S37. http://dx.doi.org/10.1016/j.drugalcdep.2006.12.015

Hart, S. D., Watt, K. A., \& Vincent, G. M. (2002). Commentary on Seagrave and Grisso. Law and human behavior, 26(2), 241-245. http://dx.doi.org/10.1023/A:1014648227688

Hopfer, C., Salomonsen-Sautel, S., Mikulich-Gilbertson, S., Min, S., McQueen, M., Crowley, T., \& ... Hewitt, J. (2013). Conduct disorder and initiation of substance use: A prospective longitudinal study. Journal Of The American Academy Of Child \& Adolescent Psychiatry, 52(5),

Kaden, M. A. (2010). African American adolescent males and conduct disorder: An examination of diagnosis and racial bias. Dissertation Abstracts International, 70, 5825.

Kahn, R. E., Frick, P. J., Youngstrom, E. A., Kogos Youngstrom, J., Feeny, N. C., \& Findling, R. L. (2013). Distinguishing primary and secondary variants of callous-unemotional traits among adolescents in a clinic-referred sample. Psychological assessment, 25(3), 966. http://dx.doi.org/10.1037/a0032880

Kimonis, E. R., Frick, P. J., Cauffman, E., Goldweber, A., \& Skeem, J. (2012). Primary and secondary variants of juvenile psychopathy differ in emotional processing. Development and psychopathology, 24(3), 1091. http://dx.doi.org/10.1017/S0954579412000557

Knox, G. W. (2004). Females and gangs: sexual violence, prostitution, and exploitation. Journal of Gang Research, 11(3), 1-15.

Loeber, R., Burke, J. D., Lahey, B. B., Winters, A., \& Zera, M. (2000). Oppositional defiant and conduct disorder: a review of the past 10 years, part I. Journal of the American Academy of Child \& Adolescent Psychiatry, 39(12), 1468-1484. http://dx.doi.org/10.1097/00004583-200012000-00007

Loeber, R., Stepp, S. D., Chung, T., Hipwell, A. E., \& White, H. R. (2010). Time-varying associations between conduct problems and alcohol use in adolescent girls: the moderating role of race. Journal of studies on alcohol and drugs, 71(4), 544. http://dx.doi.org/10.15288/jsad.2010.71.544

Lilienfeld, S. O., \& Arkowitz, H. (2007). What "psychopath" means. Scientific American Mind, 18(6), 80-81. http://dx.doi.org/10.1038/scientificamericanmind1207-80

Meier, M. H., Slutske, W. S., Heath, A. C., \& Martin, N. G. (2011). Sex differences in the genetic and environmental influences on childhood conduct disorder and adult antisocial behavior. Journal Of Abnormal Psychology, 120(2), 377-388. http://dx.doi.org/10.1037/a0022303

Moffitt, T. E. (1993). Adolescence-limited and life-course-persistent antisocial behavior: a $\begin{array}{llll}\text { developmental taxonomy. Psychological review, } & \text { 100(4), } 674 .\end{array}$ http://dx.doi.org/10.1037/0033-295X.100.4.674

Moffitt, T. E., Arseneault, L., Jaffee, S. R., Kim - Cohen, J., Koenen, K. C., Odgers, C. L., \& Viding, E. (2008). Research Review: DSM - V conduct disorder: research needs for an evidence base. Journal of Child Psychology and Psychiatry, 49(1), 3-33. 
http://dx.doi.org/10.1111/j.1469-7610.2007.01823.x

National Gang Center. National Youth Gang Survey Analysis. Retrieved November, 10, 2015, from http://www.nationalgangcenter.gov/Survey-Analysis

Newman, J. P., MacCoon, D. G., Vaughn, L. J., \& Sadeh, N. (2005). Validating a distinction between primary and secondary psychopathy with measures of Gray's BIS and BAS $\begin{array}{lllll}\text { constructs. Journal of abnormal psychology, } & 114(2), & 319 .\end{array}$ http://dx.doi.org/10.1037/0021-843X.114.2.319

Raine, A. (2013). The anatomy of violence: the biological roots of crime. Random House LLC.

Salekin, R. T., \& Frick, P. J. (2005). Psychopathy in children and adolescents: The need for a developmental perspective. Journal of Abnormal Child Psychology, 33(4), 403-409. http://dx.doi.org/10.1007/s10802-005-5722-2

Skeem, J. L., \& Cauffman, E. (2003). Views of the downward extension: Comparing the youth version of the Psychopathy Checklist with the Youth Psychopathic Traits Inventory. Behavioral Sciences \& the Law, 21(6), 737-770. http://dx.doi.org/10.1002/bsl.563

Skeem, J., Johansson, P., Andershed, H., Kerr, M., \& Louden, J. E. (2007). Two subtypes of psychopathic violent offenders that parallel primary and secondary variants. Journal of abnormal psychology, 116(2), 395. http://dx.doi.org/10.1037/0021-843X.116.2.395

Skeem, J. L., \& Cooke, D. J. (2010). Is criminal behavior a central component of psychopathy? Conceptual directions for resolving the debate. Psychological assessment, 22(2), 433. http://dx.doi.org/10.1037/a0008512

Skeem, J. L., Polaschek, D. L., Patrick, C. J., \& Lilienfeld, S. O. (2011). Psychopathic personality bridging the gap between scientific evidence and public policy. Psychological Science in the Public Interest, 12(3), 95-162. http://dx.doi.org/10.1177/1529100611426706

Snyder, H. N., \& Sickmund, M. (2006). Juvenile offenders and victims: 2006 national report. Office of juvenile justice and delinquency prevention.

Steffensmeier, D., \& Allan, E. (1996). Gender and crime: Toward a gendered theory of female offending. Annual review of sociology, 459-487. http://dx.doi.org/10.1146/annurev.soc.22.1.459

Sykes, G. M., \& Matza, D. (1957). Techniques of neutralization: A theory of delinquency. American sociological review, 664-670. http://dx.doi.org/10.2307/2089195

Taylor, T. J., Peterson, D., Esbensen, F. A., \& Freng, A. (2007). Gang membership as a risk factor for adolescent violent victimization. Journal of Research in Crime and Delinquency, 44(4), 351-380. http://dx.doi.org/10.1177/0022427807305845

Taylor, T. J. (2008). The Boulevard Ain't Safe for Your Kids... 1 Youth Gang Membership and Violent Victimization. Journal of Contemporary Criminal Justice, 24(2), 125-136. http://dx.doi.org/10.1177/1043986208315476

Taylor, T. J., Freng, A., Esbensen, F. A., \& Peterson, D. (2008). Youth gang membership and serious violent victimization: The importance of lifestyles and routine activities. Journal of Interpersonal Violence. http://dx.doi.org/10.1177/0886260508314306

Tung, I., Li, J. J., \& Lee, S. S. (2012). Child sex moderates the association between negative 
parenting and childhood conduct problems. Aggressive Behavior, 38(3), 239-251. http://dx.doi.org/10.1002/ab.21423

Uggen, C., \& Kruttschnitt, C. (1998). Crime in the breaking: Gender differences in desistance. Law and Society Review, 339-366. http://dx.doi.org/10.2307/827766

Vincent, G. M., \& Hart, S. D. (2002). Psychopathy in childhood and adolescence: Implications for the assessment and management of multi-problem youths. NATO SCIENCE SERIES SUB SERIES I LIFE AND BEHAVIOURAL SCIENCES, 324, 150-163.

Walters, G. D. (2012). Psychopathy and crime: testing the incremental validity of PCL-R-measured psychopathy as a predictor of general and violent recidivism. Law and human behavior, 36(5), 404. http://dx.doi.org/10.1037/h0093928

Webb, V. J., Ren, L., \& Marshall, I. H. (2011). A Comparative Study of Youth Gangs in China and the United States Definition, Offending, and Victimization. International Criminal Justice Review, 21(3), 225-242. http://dx.doi.org/10.1177/1057567711418825

Webster-Stratton, C. (1996). Early-onset conduct problems: Does gender make a difference?. Journal Of Consulting And Clinical Psychology, 64(3), 540-551. http://dx.doi.org/10.1037/0022-006X.64.3.540

Wiesner, M., Elliott, M. N., McLaughlin, K. A., Banspach, S. W., Tortolero, S., \& Schuster, M. A. (2015). Common versus specific correlates of fifth-grade conduct disorder and oppositional defiant disorder symptoms: Comparison of three racial/ethnic groups. Journal Of Abnormal Child Psychology, 43(5).

Wood, J. L., Alleyne, E., Mozova, K., \& James, M. (2014). Predicting involvement in prison gang activity: Street gang membership, social and psychological factors. Law and human behavior, 38(3), 203. http://dx.doi.org/10.1037/lhb0000053

Yoder, K. A., Whitbeck, L. B., \& Hoyt, D. R. (2003). Gang involvement and membership among homeless and runaway youth. Youth \& Society, 34(4), 441-467. http://dx.doi.org/10.1177/0044118X03034004003

\section{Copyright Disclaimer}

Copyright reserved by the author(s).

This article is an open-access article distributed under the terms and conditions of the Creative Commons Attribution license (http://creativecommons.org/licenses/by/3.0/). 